\title{
メロン果実污斑細菌病に対する 食酢の播種後灌注処理による防除効果
}

\author{
草野新太郎・青野昌彦・駒場雅彦・白川 隆* \\ (タキイ種苗株式会社・*野菜茶業研究所)
}

メロン果実污斑細菌病（bacterial fruit blotch）は, 病 原細菌である Acidovorax avenae subsp. citrulli (以下Aac) によって発生する病害で, Aac はスイカやメロン等のウ リ科野菜に強い病原性を示す。本病は1989年～1995年に アメリカで大発生して甚大な被害をもたらしたことよ り，植物防疫法施行規則で「輸入にあたって栽培検査を 必要とする有害動植物」に指定されている。わが国では 1998年に山形県で初めて確認されて以来，スイカ・メロ ン・トウガンで散発的に発生しているが, 発生戋場での 定着は確認されていない ${ }^{5,10,12)}$ 。本病は種子伝染性病害で もあり，全てのわが国での発生事例は $A a c$ 污染種子が原 因であると考えられていることから，種子検査技術，種 子消毒技術および栽培時の防除技術といった一連の技術 確立が急務である ${ }^{2-4,9,11)}$ 。特に種子検査や種子消毒にて 防除対応が不十分だった場合，污染種子播種後の数日間 は $A a c$ の増殖・感染を防除する時期として非常に重要と なる。そこで本研究では，スイカと同様に防除対策が求 められているメロンに関して, 特定防除資材の一つであ る食酢や食品添加物として安全性が高いとされるアスコ ルビン酸（ビタミン C $)^{1,6,7)}$ を用いて，メロン種子播種 後の灌注処理による本病の防除効果について検討した。

なお, 本研究は, 農林水産省委託事業 : 新たな農林水 産政策を推進する実用技術開発事業（旧：先端技術を活 用した農林水産研究高度化事業)の一環として実施した。

\section{材料および方法 \\ 1. $A a c$ 人工污染種子の作製}

$A a c$ 菌株には, Aac0501（メロンからの分離菌株, 2005年，茨城県）を供試した。培養はペプトン水培地を 用いて $25^{\circ} \mathrm{C}$ で72時間振盪培養後, 培養溶液を遠心分離 して得た菌体を用いた。メロン品種 ‘レノン’およびメ ロン台木用品種 “ダブルガード’ の種子を菌濃度 $10^{7}$ $10^{8} \mathrm{cfu} / \mathrm{ml}$ に調製した $A a c$ 懸濁液に浸漬し，アスピレー
ターで 30 分間（10分間を 3 回）吸引後, $35^{\circ} \mathrm{C}$ で約 12 時 間風乾した。

\section{2. 播種後の灌注処理}

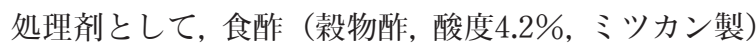
は希釈倍率を 14 倍 (酢酸濃度で約 $0.05 \mathrm{M}$ ) および70倍 (酢 酸濃度で約 $0.01 \mathrm{M}$ ）に調製したもの, アスコルビン酸（和 光純薬工業製, 試薬特級) は $0.125 \mathrm{M}$ および $0.05 \mathrm{M}$ に 調製したものを用いた。一方，比較としてカスガマイシ ン・銅水和剂（希釈倍率500倍および1,000倍）と有機銅 水和剂（希釈倍率500倍および1,000倍）を供試した。処 理は128穴セルトレイに播種培土（タキイ含水培土）を 入れて前述の人工污染種子を播種した後, 灌水の代わり として処理剤調製液を 1 セルトレイあたり $2 \mathrm{~L}$ 灌注処理 した（第 1 図）。また，食酢については防除効果のある 希釈倍率を詳細に決定するため，10，15，20，25および 50 倍希釈倍率に調製した溶液についても検討した。灌注 処理後は, 3 日間無灌水として処理剤を十分に種子に浸

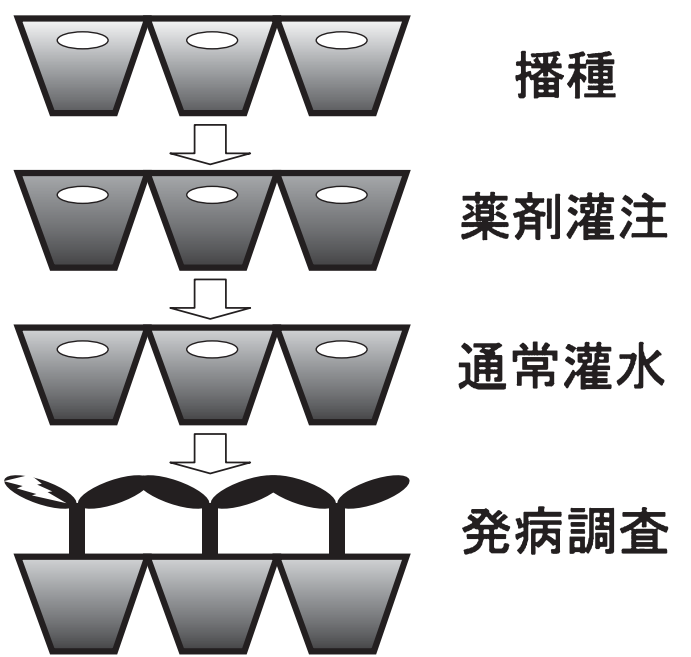

第 1 図薬剂灌注処理によるメロン果実污斑細菌病防除効果の 検定手順

Shintaro Kusano, Masahiko Aono, Masahiko Komaba and Takashi Shirakawa* (Takii \& Co., Ltd., *Nat. Inst. Veget. Tea Sci.): Control of bacterial fruit blotch of melon by treatment with vinegar after sowing 2009年 2 月 9 日受理 
透させた後に水道水を適宜灌水した。

\section{3. 薬剤防除効果の検定}

灌注処理後は平均 $25^{\circ} \mathrm{C}$ の育苗器（啓文社製作所製） 内で通常栽培し，2 週間後に発芽した苗の子葉に生じた 病斑面積率を以下に示す基準で指数化して発病度を算出 した（ 0 : 無病徵， 1 : 子葉病徵 $25 \%$ 未満, 2 : 子葉病 徵25\%～75\%, 3 : 子葉病徵75\%～枯死）。また，食酢 の詳細な希釈倍率決定には同様の栽培を行った後, 発病 株率を調査した。

\section{4. 灌注処理後の灌水時期}

食酢の灌注処理後の灌水時期の違いによる防除効果の 差異を検討した。前述の灌注処理を行い, 播種後 1,2 , 3 日目に各々水道水による灌水を十分量行った。栽培 2 週間後に発病株率を調査し，防除効果を判定した。

\section{結果および考察}

メロン污染種子播種後の食酢およびアスコルビン酸の 灌注処理によるメロン果実污斑細菌病に対する防除価 は，食酢14倍希釈溶液で100およびアスコルビン酸 0.05

第 1 表 播種後灌注処理によるメロン果実污斑細菌病防除効果

\begin{tabular}{|c|c|c|c|}
\hline 処理剤 & 処理濃度 & 発病度a) $^{\text {a) }}$ & 防除価 \\
\hline \multirow{2}{*}{ 食酢 } & 70倍 & 19.8 & 60.4 \\
\hline & 14倍 & 0 & 100 \\
\hline \multirow{2}{*}{ アスコルビン酸 } & $0.05 \mathrm{M}$ & 1.0 & 97.9 \\
\hline & $0.125 \mathrm{M}$ & 0 & 100 \\
\hline \multirow{2}{*}{$\begin{array}{l}\text { カスガマイシン・・ } \\
\text { 銅水和剂 }\end{array}$} & 1000倍 & 2.1 & 95.8 \\
\hline & 500 倍 & 1.0 & 97.9 \\
\hline \multirow{2}{*}{ 有機銅水和剂 } & 1000倍 & 40.6 & 18.8 \\
\hline & 500倍 & 30.2 & 39.6 \\
\hline 水道水 & - & 50.0 & 0 \\
\hline
\end{tabular}

各処理区とも“ダブルガード’人工污染種子 32 粒を供試。

発病指数 0 : 無病徵, 1 : 子葉病徵 $25 \%$ 未満, 2 : 子葉病徴 $25 \sim 75 \%, 3$ : 子葉病徵 $75 \%$ 枯死

a) 発病度 $=\{\Sigma($ 発病程度別株数 $\times$ 発病指数 $) \div($ 調査株数 $\times 3)\} \times 100$
M 溶液で97.9を示し, カスガマイシン・銅水和剤500倍 希釈溶液の97.9と同等か勝る効果を示した。また, 有機 銅水和剂 500 倍希釈溶液の防除価は39.6であったことか ら，食酢は本剂よりも高い防除価を示すことが明らかに なった (第 1 表)。なお, カスガマイシン・銅水和剤に ついて小木曽ら ${ }^{8)}$ は, 散布剂としてメロン果実污斑細菌 病防除への高い効果を認めており, 今回の灌注処理にお いても本剤が有効であることが確認された。

食酢の灌注処理が高い防除効果を示したことから，さ らに詳細な希釈倍率を検討した結果，10～20倍の希釈溶 液において高い防除効果を認めた（第 2 表）。また，希 䣋倍率が 7 倍（䣷酸濃度で約 $0.1 \mathrm{M}$ ）の高い食䣷濃度で は, 水道水灌注処理区と比較して子葉の展開およびその 後の植物体の生育に悪影響はなかったが, 播種 7 日後の 発芽率が10\%程度低下し, 約 1 日の発芽遅延が認められ た（第 3 表）。一方, 10倍以上の食酢濃度では水道水灌 注処理区と同等の発芽率および生育を示した。このこと から，10倍より高濃度の希釈溶液では発芽に悪影響が生 じるため実用不可能と考えられた。

食酢灌注処理後の灌水時期について検討した結果，防 除価は食酢25倍希勫溶液の灌注処理 3 日後灌水区およ び食酢10倍希釈溶液灌注処理の全灌水区で100を示した (第 4 表)。水道水灌注処理区の発病率は水道水灌注処理 後の灌水時期を早めるほど上昇したことから, 播種後の 過湿状態が発病を促しており, 食酢灌注処理後の灌水時 期が防除効果に影響すると考えられた。このことから， 灌注処理 1 日後灌水区でも防除価100であった希釈倍率 10 倍の食酢濃度は, 灌注処理後の灌水時期に影響を受け ることなく, 安定した防除効果が得られると考えられた。 以上よりメロン果実污斑細菌病に対する播種後の食酢 灌注処理は非常に高い防除効果を示したことから，メロ ン栽培時における本病の防除方法として有効と考えられ た。播種後の灌注処理といった方法では, 種子発芽中に 培土内で食酢の付着状態を形成することにより $A a c$ の増 殖・感染が阻止されると考えられる。特定防除資材であ

第 2 表 食酢灌注処理によるメロン果実污斑細菌病防除効果

\begin{tabular}{|c|c|c|c|c|c|c|}
\hline \multirow{2}{*}{ 処理剤 } & \multicolumn{3}{|c|}{ 試験 $1^{\text {a) }}$} & \multicolumn{3}{|c|}{ 試験 $2^{\mathrm{b})}$} \\
\hline & 処理濃度 & 発病株率 (\%) & 防除価 & 処理濃度 & 発病株率 (\%) & 防除価 \\
\hline \multirow[t]{3}{*}{ 食酢 } & 50倍 & 10.7 & 58.7 & 25倍 & 7.1 & 55.6 \\
\hline & 25倍 & 0 & 100 & 20倍 & 0 & 100 \\
\hline & 10倍 & 0 & 100 & 15倍 & 0 & 100 \\
\hline 水道水 & - & 25.9 & 0 & - & 16.1 & 0 \\
\hline
\end{tabular}

a) 各処理区とも ‘レノン’ 人工污染種子 28 粒を供試。

b) 各処理区とも“ダブルガード’人工污染種子 56 粒を供試。 
第 3 表 食酢灌注処理がメロン種子の発芽に与える影響

\begin{tabular}{|c|c|c|c|c|}
\hline \multirow{2}{*}{ 処理剂 } & \multicolumn{2}{|r|}{ 試験 1 ${ }^{\text {a) }}$} & \multicolumn{2}{|r|}{ 試験 $2^{\text {b) }}$} \\
\hline & 処理濃度 & 播種 7 日後の発芽率（\%) & 処理濃度 & 播種 7 日後の発芽率 (\%) \\
\hline \multirow{4}{*}{ 食酢 } & 50倍 & 100 & 25倍 & 100 \\
\hline & 25倍 & 100 & 20 倍 & 100 \\
\hline & 10倍 & 100 & 15倍 & 96.4 \\
\hline & 7倍 & 83.3 & 7倍 & 93.8 \\
\hline 水道水 & - & 96.4 & - & 100 \\
\hline
\end{tabular}

a) ‘レノン’ 人工污染種子を処理濃度 $10 ， 25 ， 50$ 倍区は 28 粒， 7 倍区は 48 粒供試。

b) ‘ダブルガード’ 人工污染種子を処理濃度 $15 ， 20 ， 25$ 倍区は 56 粒， 7 倍区は 48 粒供試。

第 4 表 食酢灌注処理後の灌水時期によるメロン果実污斑細菌病防除効果

\begin{tabular}{|c|c|c|c|c|c|c|c|}
\hline \multirow{2}{*}{ 処理剂 } & \multirow{2}{*}{ 処理濃度 } & \multicolumn{2}{|c|}{ 灌注処理 1 日後灌水 } & \multicolumn{2}{|c|}{ 灌注処理 2 日後灌水 } & \multicolumn{2}{|c|}{ 灌注処理 3 日後灌水 } \\
\hline & & 発病株率（\%） & 防除価 & 発病株率（\%) & 防除価 & 発病株率（\%） & 防除価 \\
\hline \multirow{3}{*}{ 食酢 } & 50倍 & 17.9 & 77.3 & 35.7 & 19.6 & 10.7 & 58.7 \\
\hline & 25倍 & 7.1 & 91.0 & 14.3 & 67.8 & 0 & 100 \\
\hline & 10倍 & 0 & 100 & 0 & 100 & 0 & 100 \\
\hline 水道水 & - & 78.6 & 0 & 44.4 & 0 & 25.9 & 0 \\
\hline
\end{tabular}

各処理区とも レノン'人工污染種子 28 粒を供試。

る食酢は，使用濃度，時期，回数，方法による制限がな いため，すぐに実用可能な処理剤として有望であり，メ ロン以外の他のウリ科野菜についても応用可能であると 考えられる。

\section{引用文献}

1）青野昌彦・草野新太郎・駒場雅彦・白川 隆（2008）平成 20 年度日本植物病理学会関西部会講演要旨集 p. 37。(講要)

2）窪田昌春・荻原奈央子・白川 隆 - 原 一晃 - 西 和文 （2008）日植病報 $74: 72$. (講要)

3) 原 一晃・水上涼子・島津樹一・白川 隆 (2006) 関西病 虫研報 $48: 57-60$.

4) Hopkins, D. L., C. M. Thompson, J. Hilgren and B. Lovic (2003) Plant Dis. 87: 1495-1499.
5）堀田治邦・塚本貴敬・上松 寛・安岡眞二（2006）日植病 報 $72: 82$. (講要)

6) 村田 晃・矢野信子 (1990) ビタミン $64:$ 709-713.

7）村田 晃 (1992) 防菌防徽 20:439-445.

8）小木曽秀紀・藤永真史（2008）日植病報 $74: 266$. (講要)

9）大矢仁志 - 中川寛章 - 齊藤範彦 -上松 寛 - 小原達二 （2008）日植病報 $74: 304-310$.

10）白川 隆 - 菊池繁美 - 加藤智弘 - 我孫子和雄 - 川合 昭 （2000）日植病報 $66: 223-231$.

11）鈴木輝子 - 佐藤仁敏 - 山内智史 - 大矢仁志 - 松浦貴之 - 白 川 隆（2008）日植病報 $74: 42$. (講要)

12）富田恭範・小河原孝司・白川 隆・佐藤仁敏・鹿島哲朗・ 中西 宏（2006）日植病報 $72: 312$. (講要) 